\title{
A Study on the Connotation and Path of the Ideological and Political Education into Daily Life of College Students in the Micro Era
}

\author{
Kun Wang ${ }^{1, a}$ and Jian-lei Qian ${ }^{1, b}$ \\ ${ }^{1}$ Shandong University of Finance and Economics, China \\ a12602489@qq.com, ${ }^{b} 55088392 @ q q . c o m$
}

Keywords: Micro Era, Ideological and Political Education, Life, Path

\begin{abstract}
With the advent of the micro-era, the Ideological and Political Education into Daily Life of college students has brought about profound changes to the college students' life. At the same time, it should also be enriched with the proper connotation according to the change of life. The educators engaged in ideological and political education of college students should keep pace with the times, changing their educational concepts and making full use of micro-media to bring the ideological and political education of college students into life through combination of ideological and political education of college students with the characteristics of the times. This article discusses the theme from the aspects of the relationship between education and life as well as the connotation and path of "Ideological And Political Education Into Daily Life of College Students in the Micro Era”. It aims to explore the way of "Ideological And Political Education Into Daily Life of College Students" for colleges by combining the characteristics and laws of the ideological and political education in the Micro Era, so as to provide a theoretical basis and practical method for the educators engaged in ideological and political education in colleges, and promote the further development of ideological and political education.
\end{abstract}

\section{Introduction}

With the rapid development of micro-media like Microblog and WeChat, the Micro Era has come, which greatly changes the college students' lifestyle, including their learning and reading, interpersonal communication and entertainment consumption. Therefore, the in-depth study on ideological and political education should be carried out on the basis of changing life. The wide application of new technologies in the Micro Era provides favorable conditions for the Ideological and Political Education into Daily Life, which is conducive for college students to get into the reality of life. Respecting the dominant position of college students is helpful to fully tap their living resources, combine theory with concrete reality and enrich the form and path of theoretical communication, so that their needs are met exactly. Besides, the important task of ideological and political education is to promote the comprehensive development of students, and guide them to live and learn in a better way. The micro-era environment facilitates the life of students but it also causes a lot of trouble to the same. The exploration of the Ideological and Political Education into Daily Life can not only guide the college students in their life and academic development, but also reduce the negative impact on the ideological and political education and the interference with the college students' life from the environment. Besides, it can enhance the effect of ideological and political education, contributing to the realization of objectives in ideological and political education. 


\section{Relationship between Education and Life in the Micro Era}

\subsection{Connotation of the Micro Era}

In short, the Micro Era is an era appearing with the fission-like development of network and digital technologies. It transmits the micro-contents to the micro-community and carries out micro-activities through mobile, social, inter-platform, flowing, instantaneous and flat micro-transmission forms, with micro-media like microblog and WeChat as the symbolization and mobile terminal as the communication medium. Specifically, the Micro Era has the following characteristics:

Firstly, individual and clustering

Under the micro-era background, with the continuous development of technology, all kinds of mobile intelligent terminals and a variety of applications are injected with the personalized information flow.

Secondly, rheological and instantaneous

Under the micro-era background, the continuous breakthrough of network technology and the popularity of smart phones have broken the original fixed terminal. People can use their smart phones to browse the web, get and publish information and carry out micro activities anytime and anywhere. The information spread in the Micro Era is featured as short and pithy, wide and rich in content, quick spreading and fast update.

Thirdly, diverse and uncertain

Individuals can choose micro-media according to their own interests and express their views in the micro-media, share different insights around the world, transfer and exchange ideas, culture and values from different people, regions, and countries, forming different values groups and presenting all kinds of culture and values. Many new users can identify and select the groups meeting their own values according to their own value tendency, and joint in such groups, to expand its cohesion and influence, highlighting the diversity of culture and values.

\subsection{Relationship between Education and Life}

The generalized life refers to a variety of activities carried out by people for survival and development, such as: political life, economic life, etc., of course, including a person's daily life. This life mentioned in this article means the generalized life as people's lives are affected by others and subject to the restrictions of the national system, culture and policies. In this article, the concept of "life" is expressed as a process in which people behave to meet their needs and realize a certain significance in a certain social and historical conditions, using the natural environment and social environment as the carrier.

Tao Xingzhi, one of China's famous educators, put forward "life is education." According to this point of view, the content of education is derived from the real life, while the result of education in turn guides us in the next life and practice. Specifically, the relationship between education and life is reflected from three aspects:

Firstly, education comes from life. In his book, Tao Xingzhi mentioned that "Life is education". There is no education without life. Good life leads to good education, and bad life leads to bad education. This is exactly the interpretation of "Education comes from life". Secondly, education needs life. Either the content of education or the process of education must be spread in the soil of life, and realized in the process of life. Thirdly, education guides life. Education not only should 
make people better adapt to the present life and guide their current practice, but also should lead us to create a better future and open up a more extensive world. Tao Xingzhi raised his idea of "carry out the education for improvement and progress of life", which further indicates that education should provide guidance for the better life. Therefore, our practice is carried out in life, and education should also be carried out in life.

\section{The connotation of the Ideological and Political Education into Daily Life of College Students in the Micro Era}

\subsection{The Ideological and Political Education into Daily Life should enhance the value based on the real life.}

People's life world is generated from practice, and influences and restricts people's ideas. Therefore, people's mind is closely related to the real daily life, and it is unity of the relationships between an individual and others as well as between society and life. In this case, it requires that the ideological and political education should close to life. The ideological and political education without life will become empty telling and closed system, which is utilitarian ideological and political education abandoning the inner spirit. Tao Xingzhi's theory of "life is education" is advocating to combine the education with life closely. Any ideological and political education that neglects the real life of college students is divorced from reality and cannot achieve tangible results. Therefore, the ideological and political education should return to life, and find the lost meaning and value in life. From the basic level of view, the Ideological and Political Education into Daily Life is an education concept or philosophy put forward relative to the abstraction of ideological and political education, based on the theory of the life world.

\subsection{To implement the Ideological and Political Education into Daily Life, we should focus on the students who are the major part of the life world.}

The objects of ideological and political education are living persons in the real life world, producers and creators of life and growing individuals under certain social relations and historical conditions, instead of an abstract object. "The prerequisites we begin to talk about are not arbitrary or dogmatic, but some reality that can only be put aside in imagination. This means some of the real individuals, their activities and their material living conditions, including their existing material living conditions and those to be created through their own activities." Therefore, the Ideological and Political Education into Daily Life is meaningful only when targeting at individuals in reality. The Ideological and Political Education into Daily Life should be people-oriented, understanding students, caring about students and relying on students, to make them play the initiative and enhance their consciousness of major part, so that their individual life ability and quality of life are promoted. The people's needs and happiness should be taken as the starting point and destination.

\subsection{The Ideological and Political Education into Daily Life should be committed to improving the life and enhance the quality of life}

The ideological and political education should not only return to the life world, but also build a life world really belonging to human. If the Ideological and Political Education into Daily Life is only a simple return to the real life world, it will affect the value of ideological and political education in life construction, future pointing and quality enhancement. It can be said that ideological and political education is to cultivate people not only for the existing society, but also for the future society. Therefore, the life of ideological and political education should not only based 
on real life, but also to establish the life goal of science, and constantly go beyond the real life, and on this basis to develop and play the students to enhance the ideological and political quality of the initiative and creativity, so that On the real life world initiative to abandon, and actively participate in the construction of meaningful life.

\section{Study on the Ideological and Political Education into Daily Life of College Students in the Micro Era}

Education is a multi-faceted force, and the Ideological and Political Education into Daily Life should make full use of the micro-era convenient conditions to tap more diverse channels, improving the permeability of Ideological and Political Education into Daily Life.

\subsection{Creating "micro classroom" and carrying out the ideological and political education reform with an open-up field of vision}

A classroom is the main position for the Ideological and Political Education into Daily Life. To improve the effectiveness of Ideological and Political Education into Daily Life needs to be supported by classroom teaching effect. To do a good job in ideological and political education, we must take the deepening of reform as a breakthrough. The traditional ideological and political education adopts a perfusion-style education mode in which teachers only perform teaching, and students listen to the teachers negatively, where, there is lack of communication between teachers and students, so the students have less enthusiasm and initiative in learning. In addition, some ideological and political education is obscure, showing obvious political tendencies and direct telling style, which may easily cause psychological inversion of students. With the development of technology and the popularity of smart phones, the students pay most of their attention to the virtual space of network, and even, many students frequently brush microblog, chat via WeChat, visit circle of friends and browse web pages in class, which greatly reduces the teaching effect of ideological and political education classes.

Micro classroom is an innovative mobile teaching platform. It enables schools quickly step into the mobile Internet era and makes management more convenient and efficient. Through the micro classroom, the micro class, homework and examinations are installed into a smart phone easily, to achieve learning anytime and anywhere. The micro classroom also supports on-line Q \& A, and immediate interaction at any time. Besides, the establishment of hand-held learning community avoids loneliness during learning. Micro-class can better meet the students' needs for personalized learning of different subjects, and demand-based learning, where students can strengthen and consolidate the knowledge. Therefore, it is an important supplement and expanded resource for the traditional classroom learning. "Micro classroom" has become a platform for students to achieve self-study and exploring study. Today's college students have been in the Micro Era. If the teachers cannot keep up with the pace of the times, and blindly stick to the traditional teaching mode, there will be an increasing large distance between them and the students. The Micro Era not only challenges the ideological and political education, but also provides a new opportunity for the same. Colleges can vigorously promote the "Internet + Teaching Resources" construction by combining a lot of fragmented time of college students with the real-time communication and seamless convergence of the network. The ideological and political education should rely on this situation, changing the traditional mode of ideological and political education and introducing "micro classroom" to continuously develop and construct a large number of excellent courses, professional teaching cases and renewable learning resources based on learning, internship and practice, 
according to the ideological and political classes as well as the party's innovative theoretical results and practical requirements. They can also integrate all kinds of ideological and political education resources like school historical stories, rituals, cultural and artistic activities, excellent teachers and students cases, and convert them into the network culture products like network video, cartoon animation and so on.

\subsection{Performing "micro-interaction", and entering the life of college students in a caring way}

In the Micro Era, the prerequisite to realize the ideological and political education is to enter the student's life world, especially into their micro-life of network. The college students' life is subject to delicate changes in the Micro Era. They frequently update and follow microblog, like chatting via QQ and WeChat Apps, visit circle of friends, read micro-fictions, like watching micro-videos, pay more attention to short news, get keen to seckilling on the Internet as well as other fragmented life activities. Catching up time has become the portrayal of most college students' life. Besides, the personality of college students has undergone a delicate change. They like to be recognized and concerned, with dependency enhanced, and independence weakened. The students' psychological confusions are increased. Through the "micro-interaction", then, the ideological and political educators can receive college students' "micro-life" state, understand and perceive them, and enter their lives and soul in this way on the one hand; and on the other hand, they can guide college students to recognize the lack of such life style through the "micro-interaction" and help them to concentrate on learning and seeking of truth, so that they better understand what they want, and define the study, life and work goals; get rid of a high dependence on the network, mobile phones and other media; and do a good job of self-integration; guide them to make a proper career planning; get concerned about the personal growth and development of the students, so that they are able to respond to difficulties easily whether in school or in society after graduation, creating a richer life and a better future.

\subsection{Constructing the "micro-team" and improving the micro-strength of micro-education with a good media literacy}

The Micro Era raises new requirements and challenges for the ideological and political education. To do ideological and political education work well, it is necessary to establish a "micro-team" of the ideological and political education, which can master the ideological and political education laws and have a good media literacy.

Firstly, cultivating the awareness of media literacy of ideological and political educators

Media literacy refers to people's ability to acquire, integrate, process and use media information, and ability to expand the information dissemination by making full use of the media. The ideological and political educators in colleges should regard the "micro-era" network platform as the necessary media tool for ideological and political education, and use such media to expand their subjective position, increase the right to speak, and have a good interaction with college students.

Secondly, improving the information dissemination ability of ideological and political educators

The ideological and political educators in colleges who contact with college students most in the most direct way

They should learn to make full use of the new media to carry out ideological and political education and act as a good helper and communicator for the dissemination of spirit and relevant policies between schools and students. This requires them to continue learning from students and others, and do a good job in information dissemination. 
Thirdly, carrying out practice activities to improve media literacy

Colleges should set up a special institution which will be responsible for developing the practical cultivation scheme, preparing the teaching plan and designing the teaching contents according to the current status of the media; and inviting experts to start lectures or inviting relevant training institutions to perform the practice experience training for the ideological and political educators, and providing them with books as well as equipment and other hardware and software support, so that they can better serve schools and students.

\subsection{Carrying out "micro-activities" to truly feel the practice of strengthening moral education}

The ideological and political education is a targeted ideological and practical activity. The ideological and political educators must use real feelings from the experience of practice as the goal of ideological and political education, continuously grow and enhance the sense of innovation in such process. To achieve the educational purpose of the ideological and political education, the educators should not only improve the educated individuals' awareness through theoretical knowledge, but also convert the moral norms and moral information obtained from the practical experience into their own cognition, strengthening the psychological and emotional growth, thereby, presenting the same in specific ideological and moral behaviors. The ideological and moral characters of college students in the Micro Era are susceptible to the influence of the network world. If the educators only focus on the teaching of knowledge, but ignore the students' practice and self-construction, the students can easily disconnect the knowledge from the real life. Therefore, the ideological and political education of colleges should fully tap the micro-era resources to carry out micro-activities, and guide the students to improve their awareness of major part in the activities, so that they become conscious and initiative shapers of their own soul.

The study on the Ideological and Political Education into Daily Life of College Students in the Micro Era is a systematic project and a new issue. Through the systematic analysis on the relevant connotation and characteristics of the ideological and political education of college students in the Micro Era, this article puts forward the new path for the Ideological and Political Education into Daily Life of College Students in the Micro Era, providing the reference for the ideological and political education of colleges in China and helping the ideological and political educators educate and manage the students in a better way, so that more talents will be cultivated for the state and society.

\section{Acknowledgement}

Issue source: J16ZC42. This article is a staged achievement of A Study on the Connotation and Path of the Ideological and Political Education into Daily Life of College Students in the Micro Era (Project No.: J16ZC42) for Shandong College Humanities Social Sciences Research Plan Project 2016 (special project of ideological and political education).

\section{References}

[1] Zhao Donghua. Research on the life of ideological and political education in colleges. Shenyang Normal University. Master's thesis

[2] Zhao Chongfeng. Analysis on Problems in Ideological and Political Education into Daily Life of College Students [J]. Ideological Education Research .2012 (5) 75-78.

[3] Zhang Guoqi. Discussion on the development degree of Ideological and Political Education 
into Daily Life [J]. Ideological and theoretical education. 2009.31 (7) 28-31.

[4] Shen Peihui. Research on the ideological and political education of college students in the Micro Era based on the perspective of communication [J]. Journal of College Counselor, 2013 5 (4) $1-5$.

[5] Guo Hongming. Microblog and ideological and political education of life to turn the theory of convergence and its value [J]. Journal of Beijing University of Posts and Telecommunications (Social Science Edition), 201315 (4) 1-5.

[6] Cao Dexin. On the "micro-era" under the background of ideological and political education of college students [J]. School party building and ideological and political education .2015 (1) 63-65.

[7] Tao Xingzhi Complete Works. Volume 4 [M]. Chengdu: Sichuan People's Publishing House .1991: 65 . 